\title{
Molecular Variability of Fusarium verticillioides (Sacc.) in Maize from Three Agro-Ecological Zones of Southwest Nigeria
}

\author{
Olumayowa Mary Olowe, Adeboyega Christopher Odebode, Odunayo Joseph Olawuyi, \\ Ayodele Adegboyega Sobowale
}

Department of Botany, University of Ibadan, Ibadan, Nigeria

Email: mayolowe@yahoo.com

How to cite this paper: Olowe, O.M., Odebode, A.C., Olawuyi, O.J. and Sobowale, A.A. (2017) Molecular Variability of Fusarium verticillioides (Sacc.) in Maize from Three Agro-Ecological Zones of Southwest Nigeria. American Journal of Molecular Biology, 7, 30-40.

http://dx.doi.org/10.4236/ajmb.2017.71003

Received: June 14, 2016

Accepted: December 27, 2016

Published: December 30, 2016

Copyright $\odot 2017$ by authors and Scientific Research Publishing Inc. This work is licensed under the Creative Commons Attribution International License (CC BY 4.0).

http://creativecommons.org/licenses/by/4.0/

(c) (i) Open Access

\begin{abstract}
This study investigated the characterisation of Fusarium verticillioides strains using Amplified Fragments Length Polymorphism (AFLP) EcoR1-G/ Mse1-C primer combination. This was done to determine the amount of genetic variability present in $F$. verticillioides population. The objective of this study is to carry out molecular characterization of $F$. verticillioides strains from infected ear of maize. Six isolates were obtained in maize ear from 10 locations in three agro-ecological zones of Southwest Nigeria. Polymorphic bands detected were 164 from one base extension of EcoR1 and Mse1 primers in the selective amplification. Primer combination EC + MC produced the highest polymorphic bands of 58, while primer combination ET + MC had the highest percentage polymorphism (100\%). Genetic similarity (67\%) was observed among strains from Ibadan (IBD) (34, 36), Igbooho (IGH) (39), Ado-Ekiti (EKT) $(46,47)$, Saki (SAK) (52) and Igboora (IGB) (57, 58, 59 and 60). Strains 19 and 20 from Ilesha (ILH) had the highest pairwise similarity coefficient at $97 \%$ grouped in cluster II. The dendrogram delineated $F$. verticillioides strains into four major cluster groups with $77 \%$ similarity and other sub-groups within. Fusarium verticillioides strains could therefore be heterogeneous, and thus amplified fragment length polymorphism is an ideal tool for distinguishing the pathogenic variants of Fusarium verticillioides.
\end{abstract}

\section{Keywords}

Fusarium verticillioides, Amplified Fragment Length Polymorphism, Southwest Nigeria, Maize

\section{Introduction}

Maize is one of the staple foods for most of the population especially in areas adaptable 
for their production [1]. It is a major cereal crop for livestock feed and human nutrition [2] [3] [4] [5]. Though, its production in Nigeria is constrained by biotic factors such as pests and diseases [2].

Fusarium verticillioides (Sacc.) is a maize pathogen causing root, stalk and ear rots in Nigeria [6] [7]. It is found in plant residue in almost every maize field at harvest which its symptoms vary widely and range from asymptomatic plants to severe rotting of all plant parts [8]. Symptomless infection exists in maize leaves, stems, roots and grains whereby its presence is ignored in many cases because it does not cause visible damage to the plant [9]. This suggests that some strains of $F$. verticillioides produce disease in maize while others do not [10].

The knowledge of variability in pathogen is required by host resistance to develop effective disease management strategies [11]. Conventional markers used to study the variability in pathogens are based on the use of differential hosts, culture characteristics, morphological markers and biochemical tests [12] [13]. These markers distinguished pathogens on the basis of the physiological characters such as pathogenicity and growth behaviours which are highly influenced by the host age, inoculum quality and environmental condition. The use of molecular markers is therefore necessary.

The genetic characterisation of Fusarium species using several molecular techniques has been adopted; they are RAPD (Random Amplified Polymorphic DNA), PCRRFLP (Polymerase Chain Reaction-Restriction Fragment Length Polymorphism), AFLP (Amplified Fragment Length Polymorphism) [14]. The application of AFLP in DNA fingerprinting of microbes particularly fungi had been reported [15] [16]. This technique provides a high degree of flexibility due to different restriction enzymes, the nature and number of selective nucleotides that can be manipulated to limit amplification fragments generated in order to account for differences in genome size.

This study aimed to assess the genetic relatedness of $F$. verticillioides from maize in three agro-ecological zones of Southwest Nigeria.

\section{Materials and Methods}

\subsection{Collection of Diseased Maize Samples}

Six maize ear showing rot symptoms were randomly obtained from Derived Savanna (Ilora, Ijebu-Ode, Igboora and Eruwa), Rainforest (Ado-Ekiti, Akure, Ilesa and Ibadan) and Guinea Savanna (Saki, Igboho) of Southwest Nigeria between May to July, 2013.

\subsection{Isolation of Fusarium verticillioides}

Some infected and healthy grains obtained from the sampled maize ear were washed under running water, surface sterilized for one minute in $10 \%$ sodium hypochlorite solution, and then rinsed in three changes of sterile water, followed by drying with sterile paper towel. These were then placed on solidified potato dextrose agar in petri-dishes and incubated at room temperature $\left(28^{\circ} \mathrm{C} \pm 2^{\circ} \mathrm{C}\right)$ for 7 days. Observation was made daily on mycelial growth. Pure cultures were obtained by subculturing onto fresh plates. 


\subsection{Morphological Characteristic of Fusarium verticillioides}

Morphological identification according to [17] and [18] was carried out at the pathology unit of International Institute of Tropical Agriculture (IITA) Ibadan. Morphological identification of $F$. verticillioides involved observable characters on the cultured plates (rate of growth, pigment production, presence or absence of mycelium and mycelium colour), while the microscopic identification involved distinctive structures and characters (phialides, chlamydospores, microconidia and macroconidia).

\subsection{Extraction of Genomic DNA of Fusarium verticillioides}

Genomic DNA was extracted using a DNeasy tissue kit according to the manufacturer's instruction. DNA was eluted in $200 \mu \mathrm{l}$ of elution buffer (buffer AE of the kit) and stored at $-20^{\circ} \mathrm{C}$. DNA yield were measured using Nanodrop spectrophotometer, while the quality was assessed by agarose gel electrophoresis, restriction enzyme digestion and AFLP analyses using the procedure described by [19].

\subsection{Restriction and Ligation of Adapters}

Two restriction endonucleases, EcoRI and Mse1 were used to digest $100 \mathrm{ng}$ of genomic DNA in $10 \mu \mathrm{L}$ reaction, which was incubated for $37^{\circ} \mathrm{C}$ for 3 hours and inactivated at $70^{\circ} \mathrm{C}$ for 15 minutes. Digested and undigested DNA were separated on $1 \%$ agarose gels in TBE buffer. The ligation reaction volume of $10 \mu \mathrm{l}$ was prepared to contain of $5 \mathrm{U}$ of T4 DNA ligase, ligase buffer $100 \times \mathrm{BSA}, 5 \mu \mathrm{M}$ EcoRI (Forward and reverse) and $50 \mu \mathrm{M}$ MseI (forward and reverse). After combining $10 \mu \mathrm{L}$ of ligation mix with the digested DNA fragment, ligation was allowed to proceed for 5 hours at $37^{\circ} \mathrm{C}$. The adapter-ligated DNA $(20 \mu \mathrm{L})$ was diluted 1:5 with autoclaved water to serve as template in the pre-selective PCR and was stored at $-20^{\circ} \mathrm{C}$.

\subsection{Pre Selective and Selective PCRs}

The description of the adapters for pre-amplification and selective amplification primer sequence used in this study is shown in Table 1. Pre-selective amplification of the dilute template DNA was carried out with AFLP primer combinations (5 $\mu \mathrm{M}$ Pre EcoRI and $50 \mu \mathrm{M}$ Pre MseI) without selective nucleotides and twenty microliter PCR reactions containing $8.0 \mu \mathrm{l}$ of dilute template DNA, $2.0 \mu \mathrm{l}$ of PreEcoRI (5 UM), $0.2 \mu \mathrm{l}$ of PreMseI ( $5 \mathrm{UM}$ ) primer, $5 \mu / \mathrm{Ul}$ of Taq DNA polymerase, $2 \mu \mathrm{l}$ of $10 \times$ Taq DNA polymerase buffer, $0.6 \mu \mathrm{l}$ of $10 \mathrm{mM}$ DNTPs and $0.6 \mu \mathrm{l}$ of $50 \mathrm{mM}$ of $\mathrm{Mg}_{2}$ were performed. Pre-amplification reactions were performed for 20 cycles of: $30 \mathrm{~s}$ at $94^{\circ} \mathrm{C}, 30 \mathrm{~s}$ at $94^{\circ} \mathrm{C}, 56^{\circ} \mathrm{C}$ at 30 $\mathrm{s}$ and $1 \mathrm{~min}$ at $72^{\circ} \mathrm{C}$. Following pre-amplification, the reactions were diluted 10 folds with autoclaved water and used as template for selective amplification. Selective amplification were performed using three (3) selected combination of primers with one selective nucleotides (EcoRI $+\mathrm{T}, \mathrm{EcoRI}+\mathrm{G}$, EcoRI $+\mathrm{C})$ and one MseI primers $(\mathrm{MseI}+$ C). The reactions were carried out in volumes of $20 \mu \mathrm{l}$ of PCR buffer containing $6 \mu \mathrm{l}$ of dilute preamplified template DNA, $0.2 \mu \mathrm{l}$ of $10 \mathrm{ng}$ EcoRI, $0.7 \mu \mathrm{l}$ of $10 \mathrm{ng}$ MseI, $0.3 \mu \mathrm{l}$ of $10 \mathrm{mM}$ dntps, $2 \mu \mathrm{l}$ of reaction buffer and $0.3 \mu \mathrm{l}$ of $50 \mathrm{nM}$. The program ran for 11 cycles at $94^{\circ} \mathrm{C}$ for $30 \mathrm{~s}, 94^{\circ} \mathrm{C}$ for $30 \mathrm{~s}, 72^{\circ} \mathrm{C}$ for $60 \mathrm{~s}, 94^{\circ} \mathrm{C}$ for $30 \mathrm{~s}, 56^{\circ} \mathrm{C}$ for $30 \mathrm{~s}$ and $72^{\circ} \mathrm{C}$ for 60 s. $7 \mu \mathrm{l}$ of formaldehyde dye was added to $20 \mu \mathrm{l}$ of each sample and the samples were 
Table 1. Description of the primers used for amplified fragment length polymorphism.

\begin{tabular}{cc}
\hline Primers and their functions & Sequences (5'-3') \\
\hline EcoRI-Adapters 1 and 2 & \\
E A 1.1 & CTCGTAGACTGCGTACC \\
E A 1.2 & ATTGGTACGCAGTCTAC \\
MseI-Adapters 1 and 2 & \\
M A 1.1 & GACGATGAGTCCTGAG \\
M A 1.2 & TACTCAGGACTCAT \\
Preamplification & \\
Pre EcoRI $(+0)$ & \\
Pre MseI $(+C)$ & GTAGACTGCGTACCAATTC \\
Selective amplification & ACGATGAGTCCTGAGTAAC \\
EcoRI $+\mathrm{C}$ & \\
EcoRI $+\mathrm{T}$ & \\
EcoRI $+\mathrm{C}$ & AGACTGCGTACCAATTCC \\
MseI $+\mathrm{C}$ & AGACTGCGTACCAATTCT \\
& AGACTGCGTACCAATTCG \\
& GATGAGTCCTGAGTAAC
\end{tabular}

Source: [16].

denatured for 5 minutes at $95^{\circ} \mathrm{C}$. Each sample was loaded on a $6 \%$ polyacrylamide gel containing $400 \mu \mathrm{l}$ ammonium persulphate (APS). Gels were cast using long and short plates with $0.25 \mathrm{~mm}$ thick spacers and comb. The long plates were treated with sigmacote, while the short plates were treated with a binding solution. Electrophoresis was performed at a constant power $60 \mathrm{~W}$ and a constant temperature of $47.5^{\circ} \mathrm{C}$ for $3 \mathrm{~h}$. Amplicons were revealed with silver nitrate stain.

\subsection{Data Analysis}

For each primer combination, all bands were manually recorded for presence (1) or absence (0) of each band in AFLP analysis. Bands of different electrophoretic mobility were assumed to be non-allelic, while bands of the same mobility were assumed to be allelic. A dendrogram was constructed from the similarity matrix using unweighted pair group method with arithmetic average (UPGMA) described by Sneath and Sokal (1973). Cluster analysis was performed using NTSYSpc (NTSYS-For Numerical Taxonomy System) version 2.1 [20].

\section{Results}

A total number of 164 bands were produced from three primer combinations out of which 135 were polymorphic, and correspond to an average of 45 polymorphic bands per primer combination (Table 2). Most of the bands were polymorphic, while few were monomorphic. The maximum number of bands generated by EC + MC combination was 61 bands while the minimum obtained with EG + MC primer combination was 50 bands (Figure 1). The polymorphic information content (PIC) for each marker varied between 0.7734 and 0.8249 , EG $+\mathrm{MC}$ and $\mathrm{ET}+\mathrm{MC}$ primer combinations had the maximum with the same PIC values, while ET + MC primer combination had the lowest PIC value (Table 2).

The Fusarium verticillioides strains were grouped into five (5) clusters from three (3) Agro-ecological zones. The cluster three (3) had the highest number of $F$. verticillioides strains from Ilora $(2,3,4,5,6)$, Ilesha (21), Akure $(26,27,29)$, Ibadan $(31,32)$, Igbooho 
Table 2. Characterisation of the Amplified Fragment Length Polymorphism (AFLP) primers based on Polymorphic Information Content (PIC).

\begin{tabular}{cccccc}
\hline Primer combination & NPB & TNB & PPB & PIC & AN \\
\hline EG + MC & 40 & 50 & 80.0 & 0.8249 & 59 \\
ET + MC & 45 & 53 & 84.9 & 0.7734 & 58 \\
EC+MC & 50 & 61 & 82.0 & 0.8249 & 59 \\
& & & & & \\
Total & 135 & 164 & 246.9 & 2.4232 & 176 \\
Mean & 45 & 54.7 & 82.3 & 0.8077 & 58.7 \\
\hline
\end{tabular}

NPB: Number of Polymorphic Bands, TNB: Total Number of Bands, PPB: Percentage Polymorphic Bands, AN: Allele Number.

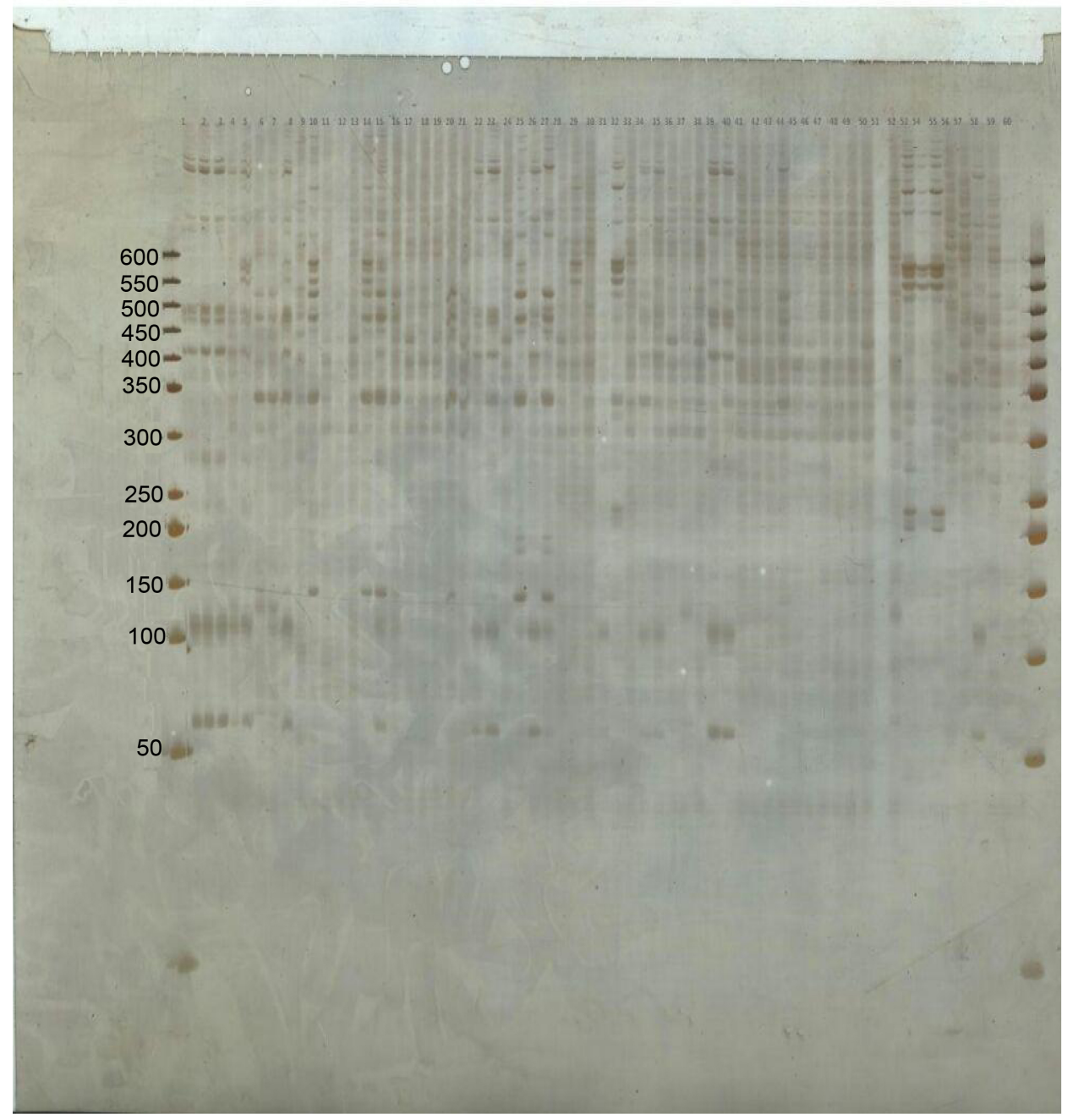

Figure 1. Amplified Fragment Length Polymorphism (AFLP) Products from Fusarium verticillioides strains using EcoRI-G/MseI-C Primer Combination.

(38, 41, 42), Ado-Ekiti (43, 44, 45) and Saki (53), while cluster I recorded the least number of $F$. verticillioides strains (Table 3 ). 
The genetic relationships of $F$. verticillioides strains were also represented in the dendrogram (Figure 2). The coefficient of similarity ranged from 0.67 to 0.97 . There were five main clusters constituting all samples with similarity coefficient of 0.72 . Group 1 had two subgroups consisting of six strains; 1 (ILR), 10 (ERW), 49 (SAK), 25 (AKR), 33 (IBD) and 24 (ILH). 24 (ILH) had the highest genetic distance within the group. The group II in the dendrogram had 2 sub-groups of $10 \mathrm{~F}$. verticillioides strains of which the highest occurrence were from Eruwa (ERW), though, strains 17 (IJB) was the most distanced within the group. Group I and II had coefficient similarity at 0.87 , while Group III with 5 sub-groups had the highest number of strains. Strains 2 and 3 (ERW) formed coefficient similarity with strains 4 and 5 (ERW) at 0.876 , while strains 6 (ERW) and 29 (AKR) were the most distanced within the group. The fourth group had 5 subgroups containing 16 isolates in which strain 54 from SAK was the most distanced within the group. Strains from IBD $(34,36)$, IGH $(39)$, EKT $(46,47)$, SAK (52) and IGB $(57,58,59$, and 60$)$ were distinctly separated from other strains at 0.67 similarities. The closest strains are 19 and 20 in cluster II from ILH, with the highest pairwise similarity coefficient of 0.97 (Figure 2).

\section{Discussion}

Understanding the diversity of pathogens is necessary to predict the control measures, which include; the use of resistant cultivar, fungicides application or the use of biological agents [21]-[26]. The detected 164 AFLP bands in which 135 were polymorphic (82\% polymorphic rate) indicates high genetic diversity in accordance with the findings of [27] and [28] who reported genetic similarity between and among the isolates. Genetic similarity between the isolates which ranged from 0.67 to 0.97 for similar coefficient index is an indication of genetic variation as similarly reported by [29].

It was shown that polymorphism was present in the PCR products from the $F$. verticillioides strains with the AFLP primers used in characterization. There was no association between AFLP patterns and agro-ecological origin of the tested strains, again, the

Table 3. Cluster groups of Fusarium verticillioides strains from the three agro-ecological zones.

\begin{tabular}{|c|c|c|}
\hline Cluster group & Total number of strains & Strain codes \\
\hline I & 6 & $\begin{array}{l}1,10,49 \\
25,33,24\end{array}$ \\
\hline II & 10 & $\begin{array}{c}11,12,13,14 \\
15,16,18,19,20,17\end{array}$ \\
\hline III & 18 & $\begin{array}{c}2,3,4,5,21,26, \\
27,31,32,41,42, \\
43,44,45,38,53,6,29\end{array}$ \\
\hline IV & 16 & $\begin{array}{c}37,40,48,22 \\
23,28,30,35,50 \\
51,55,56,7,8,9,54\end{array}$ \\
\hline $\mathrm{V}$ & 10 & $\begin{array}{c}34 \\
36,39 \\
46,47,52 \\
57,58,59,60\end{array}$ \\
\hline
\end{tabular}




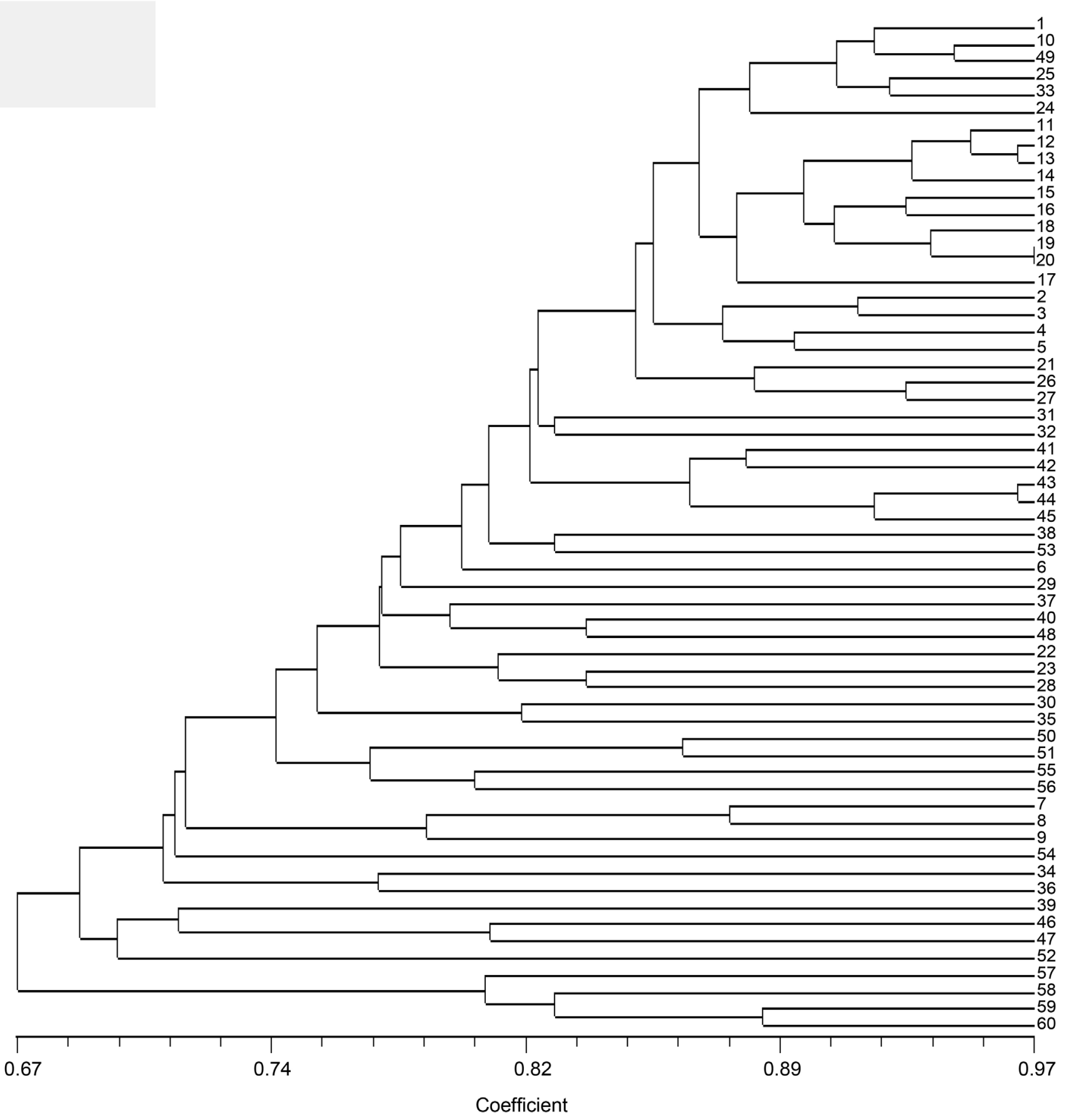

Figure 2. Dendrogram showing Fusarium verticillioides strains using three (3) AFLP Primer Combination. Samples: 1-6 (Eruwa), 7-12 (Akure), 13-18 (Ibadan), 19-24 (Ilesa), 25-30 (Igbooho), 31-36 (Saki), 37-42 (Ekiti), 43-48 (Igboora), 49-54 (Ijebu), 55-60 (Ilora).

biology and epidemiology of this pathogen may provide some insight as to during favourable condition. $F$. verticillioides causes many diseases such as root, stalk and ear rots, which is responsible for the decrease in nutritive value, loss in germination, discoloration, increase in fatty acid and secretion of mycotoxins which results in losses of maize production [30] [31] [32] [33] [34].

The dendrogram based on the genetic similarity coefficient established the interrelationship among the isolates from different locations in the three agroecological zones. 
The clustering pattern of the isolates, irrespective of the source implies that the genetic distance is not correlated with the agro-ecological distance as similarly reported by [35]. The genetic similarity obtained through AFLP analysis showed level of genetic variation among the strains. The strains do not depicts close relatedness with each other, and strains from different location showed a common clad which supports that migration event are common in the population of $F$. verticillioides as similarly observation was reported by [36].

Random mating population displays a high degree of genotypic diversity due to difficulties in the management of disease as a result of constant appearance of new strains which increase the variability features like fungicides resistance, higher aggressiveness and better fitness in the population [28]. Other factors that could be responsible for increase in genetic diversity are mutation, translocation, chromosomal deletion are common in fungi as well as difference in climatic condition where the isolates were collected [28] [37].

\section{Conclusion}

In conclusion, molecular characterisation of Fusarium verticillioides was investigated to give the genetic variability. Amplified fragment length polymorphism markers should be encouraged in studying the genetic variation in natural population of $F$. verticillioides which can help pathologists to detect the pathogenic potential of this pathogen as well as helping to develop an effective control strategy.

\section{Conflict of Interests}

There is no any kind of conflict of interests with any trademark mentioned in this paper, competitive interest, or secondary interest that could have influenced the research. This declaration is carried out by all the authors of the work presented.

\section{Funding}

This research did not receive any specific grant from funding agencies in the public, commercial, or not-for-profit sectors.

\section{References}

[1] Ofor, M.O., Ibeawuchi, I.I. and Oparaeke, A.M. (2009) Crop Protection Problems in Production of Maize and Guinea Corn in Northern Guinea Savanna of Nigeria and Control Measures. Nature and Science, 7, 8-14.

[2] Akande, S.R. and Lamidi, G.O. (2006) Performance of Quality Protein Maize Varieties and Disease Reaction in the Derived-Savanna Agro-Ecology of South-West Nigeria. African Journal of Biotechnology, 5, 1744-1748.

[3] Olakojo, S.A., Omueti, O., Ajomale, K. and Ogunbodede, B.A. (2007) Development of Quality Protein Maize: Biochemical and Agronomic Evaluation. Tropical and Subtropical Agroecosystems, 7, 97-104.

[4] Olawuyi, O.J., Odebode, A.C., Alfar, A., Olakojo, S.A. and Adesoye, A.I. (2010) Performance of Maize Genotypes and Arbuscular Mycorrhizal Fungi in Samara District of South West Region of Doha-Qatar. Nigerian Journal of Mycology, 3, 86-100.

[5] Olowe, O.M., Olawuyi, O.J. and Odebode, A.C. (2015) Response of Maize Genotypes to 
Fusarium verticillioides Strains from Two Agro Ecological Zones in Southwest Nigeria. International Journal of Pure and Applied Sciences and Technology, 27, 77-86.

[6] Olawuyi, O.J., Babatunde, F.E., Akinbode, O.A., Odebode, A.C. and Olakojo, S.A. (2011) Influence of Arbuscular Mycorrhizal and N.P.K Fertilizer on the Productivity of Cucumber (Cucumis sativus). International Journal of Organic Agriculture Research \& Development, 3, 22-31.

[7] Sobowale, A.A., Odebode, A.C., Cardwell, K.F. and Bandyopadhyay, R. (2009) Suppression of Growth of Fusarium verticillioides Niren. Using Strains of Trichoderma harzianum from Maize (Zea mays) Plant Parts and Its Rhizosphere. Journal of Plant Protection Research, 49, 452-459. https://doi.org/10.2478/v10045-009-0072-7

[8] Parsons, M.W. (2008) Biotic and Abiotic Factors Associated with Fusarium Ear Rot of Maize Caused by Fusarium verticillioides. Ph.D. Dissertation, Iowa State University, Ames.

[9] Munkvold, G.P. and Desjardins, A.E. (1997) Fumonisins in Maize: Can We Reduce Their Occurrence? Plant Disease, 81, 556-565. https://doi.org/10.1094/PDIS.1997.81.6.556

[10] Bacon, C.W. and Williamson, J.W. (1992) Interactions of Fusarium moniliforme, Its Metabolites and Bacteria with Corn. Mycopathologia, 117, 65-71.

https://doi.org/10.1007/BF00497280

[11] Sharma, T.R. (2003) Molecular Diagnosis and Application of DNA Markers in the Management of Fungal and Bacterial Plant Diseases. Indian Journal of Biotechnology, 2, 99-109.

[12] Haque, S., Park, R.F., Keiper, F.J., Bariana, H.S. and Wellings, C.R. (2008) Pathogenic and Molecular Variation Support the Presence of Genetically Distinct Clonal Lineages in Australian Populations of Puccinia graminis f. sp. avenae. Mycological Research, 112, 663-673. https://doi.org/10.1016/j.mycres.2008.01.015

[13] Zhang, J., Torriani, S.F.F. and McDonald, B.A. (2007) Significant Difference in Pathogenicity between MAT1-1 and MAT1-2 Isolates in the Wheat Pathogen Mycosphaerella graminicola. Fungal Genetics and Biology, 44, 339-346.

https://doi.org/10.1016/j.fgb.2006.10.008

[14] Mitter, N., Srivastava, A.C., Ahamad, R.S., Sarbhoy, A.K. and Agarwal, D.K. (2001) Characterization of Gibberellin Producing Strains of Fusarium moniliforme Based on DNA Polymorphism. Mycopathologia, 153, 187-193. https://doi.org/10.1023/A:1014946217539

[15] Leisová, L., Hanzalová, A. and Kucera, L. (2008) Genetic Diversity of Pyrenophora tritici-repentis Isolates as Revealed by AFLP Analysis. Journal of Plant Pathology, 90, 233-245.

[16] Prom, L.K., Perumal, R. and Erattaimuthu, S.R. (2011) Virulence and Molecular Genotyping Studies of Sporisorium reilianum Isolates in Sorghum. Plant Disease, 95, 523-529. https://doi.org/10.1094/PDIS-10-10-0720

[17] Nelson, P.E., Toussoun, T.A. and Marasas, W.F.O. (1983) Fusarium Species: An Illustrated Manual for Identification. Pennsylvania State University Press, Pennsylvania.

[18] Leslie, J.F. and Summerell, B.A. (2006) The Fusarium Laboratory Manual. Blackwell, Oxford, 388 p. http://dx.doi.org/10.1002/9780470278376

[19] Vos, P., Hogers, R., Bleeker, M., Reijans, M., van de Lee, T., Hornes, M., Freijters, A., Pot, J., Peleman, J., Kuiper, M. and Zabeau, M. (1995) AFLP: A New Concept for DNA Fingerprinting. Nucleic Acids Research, 21, 4407-4414. https://doi.org/10.1093/nar/23.21.4407

[20] Ramasamy, P., Frederiksen, R.A., Prom, L.K. and Magill, C.W. (2007) Head Smut. In: Thakur, R., Reddy, B. and Mathur, K., Eds., Screening Techniques for Sorghum Diseases, International Crops Research Institute for the Semi-Arid Tropics (ICRISAT), Patancheru, 5863.

[21] Cumagun, C.J.R. (2007) Population Genetics of Plant Pathogenic Fungi with Emphasis on 
Fusarium Species. The Philippine Agricultural Scientist, 90, 244-256.

[22] Heydari, A. (2007) Biological Control of Turfgrass Fungal Diseases. In: Pessarakli, M., Ed., Turfgrass Management and Physiology, CRC Press, Boca Raton, 223-235. https://doi.org/10.1201/9781420006483.ch13

[23] Huang, R., Galperin, M., Levy, Y. and Perl-Treves, R. (1997) Genetic Diversity of Fusarium moniliforme Detected by Vegetative Compatibility Groups and Random Amplified Polymorphic DNA Markers. Plant Pathology, 46, 871-881. https://doi.org/10.1046/j.1365-3059.1997.d01-91.x

[24] Odebode, A.C., Ladoye, A.O. and Osonubi, O. (1995) Influence of Arbuscular Mycorrhizal Fungi on Disease Severity of Pepper and Tomato Caused by Sclerotium rolfsii. Journal of Science Research, 2, 49-52.

[25] Olawuyi, O.J., Odebode, A.C., Oyewole, I.O., Akanmu, A.O. and Afolabi, O. (2013) Effect of Arbuscular Mycorrhizal Fungi on Pythium aphanidermatum Causing Foot Rot Disease on Pawpaw (Carica papaya L.) Seedlings. Archives of Phytopathology and Plant Protection, 47, 185-193. https://doi.org/10.1080/03235408.2013.806079

[26] Sobowale, A.A., Cardwell, K.F., Odebode, A.C., Bandyopadhyay, R. and Jonathan, S.G. (2005) Growth Inhibition of Fusarium verticillioides (Sacc.) Nirenberg by Isolates of Trichoderma pseudokoningii Strains from Maize Plant Parts and Its Rhizosphere. Journal of Plant Protection Research, 45, 249-266. https://doi.org/10.2478/v10045-009-0072-7

[27] Mishra, A.K., Sharma, K. and Misra, R.S. (2010) Isozyme and PCR-Based Genotyping of Epidemic Phytophthora colocasiae Associated with Taro Leaf Blight. Archives of Phytopathology and Plant Protection, 43, 1367-1380.

[28] Nath, V.S., Sankar, M.S., Hegde, V.M., Jeeva, M.L., Misra, R.S. and Veena, S.S. (2012) Analysis of Genetic Diversity in Phytophthora colocasiae Using RAPD Markers. Asian and Australasian Journal of Plant Science and Biotechnology, 6, 38-43.

[29] Prabhu, H.V., Adiver, S.S., Bhat, R., Narayana, Y.D., Jahagirdar, S. and Parameshwarappa, K.G. (2012) Genetic Variability in Macrophomina phaseolina (Tassi.) Goid., Causal Agent of Charcoal Rot of Sorghum Karnataka. The Journal of Agricultural Science, 25, 72-76.

[30] Abd-Elsalam, K.A., Khalil, M.S., Aly, A.A. and Asran-Amal, A. (2002) Genetic Diversity among Fusarium oxysporum f. sp. vasinfectum Isolates Revealed by UP-PCR and AFLP Markers. Phytopathologia Mediterranea, 41, 252-258.

[31] Kiprop, E.K., Baudoin, J.P., Mwang’ombe, A.W., Kimani, P.M., Mergeai, G. and Maquet, A. (2002) Characterization of Kenyan Isolates of Fusarium udum from Pigeon Pea (Cajanus cajan (L.) Millsp.) by Cultural Characteristics, Aggressiveness and AFLP Analysis. Journal of Phytopathology, 150, 517-527. https://doi.org/10.1046/j.1439-0434.2002.00798.x

[32] Machon, P., Pajares, J.A., Diez, J.J. and Alves-Santos, F.M. (2006) Influence of the Ectomycorrhizal Fungus Laccaria laccata on Pre-Emergence, Post-Emergence and Late Damping-Off by Fusarium oxysporum and F. verticillioides on Stone Pine Seedlings. Symbiosis, 49, 101-109. https://doi.org/10.1007/s13199-009-0015-0

[33] Mohmed, A.A., Mohmed, S.K., Mohmed, I.N., Kamel, A.A. and Joseph, A.V. (2003) Molecular Phylogeny of Fusarium Species by AFLP Fingerprint. African Journal of Biotechnology, 2, 51-55. https://doi.org/10.5897/AJB2003.000-1010

[34] Yates, I.E., Arnold, J.W., Hinton, D.M., Basinger, W. and Walcott, R.R. (2003) Fusarium verticillioides Induction of Maize Seed Rot and Its Control. Canadian Journal of Botany, 81, 422-428. https://doi.org/10.1139/b03-034

[35] Shekhar, M., Sharma R.C., Lokendra, S. and Ram, D. (2006) Genetic Variability of Macrophomina phaseolina (Tassi) Goid., Incitant of Charcoal Rot of Maize in India. Indian Phytopathology, 59, 453-459.

[36] Singh, P.K. and Hughes, G.R. (2006) Genetic Similarity among Isolates of Pyrenophora tri- 
tici-repentis, Causal Agent of Tan Spot of Wheat. Journal of Phytopathology, 154, 178-184. https://doi.org/10.1111/j.1439-0434.2006.01083.x

[37] Goodwin, S.B. (1997) The Population Genetics of Phytophthora. Phytopathology, 87, 462473. https://doi.org/10.1094/PHYTO.1997.87.4.462

Submit or recommend next manuscript to SCIRP and we will provide best service for you:

Accepting pre-submission inquiries through Email, Facebook, LinkedIn, Twitter, etc. A wide selection of journals (inclusive of 9 subjects, more than 200 journals) Providing 24-hour high-quality service User-friendly online submission system Fair and swift peer-review system Efficient typesetting and proofreading procedure Display of the result of downloads and visits, as well as the number of cited articles Maximum dissemination of your research work

Submit your manuscript at: http://papersubmission.scirp.org/ Or contact ajmb@scirp.org 